\title{
CSR Impact on the Firm Market Value: Evidence from Tour and Travel Companies Listed on Chinese Stock Markets
}

\author{
Jung Wan LEE ${ }^{1}$
}

Received: March 14, 2020 Revised: May 24, 2020 Accepted: June 10, 2020

\begin{abstract}
The study examines the impact of corporate social responsibility (CSR) activity on the firm market value, in particular, market capitalization of tour operators listed on Chinese stock markets. This study employs panel data analysis methods to examine endogeneity concerns in observational data. The balanced panel data includes a total of 1,296 observations with 27 cross-sections of tour operators listed on Chinese stock markets and with 48 time-specific periods from March 2006 to December 2017. The results indicate that CSR activity has a negative impact on the market value of the firm for the concurrent period, but from one-period time lag and afterwards CSR activity has a strong positive impact on the market value and sustains its positive impact on the market value even for a two-period time lag. The findings suggest that the economic effect of CSR activity on the firm market value tends to take some degree of lagged effects to be fully showcased in the market capitalization of tour operators and travel companies listed on Chinese stock markets. The findings suggest that, though CSR activity may carry some financial risk for an immediate short-term, tour operators must put a lot of time and effort into making CSR actions effective.
\end{abstract}

Keywords: Corporate Social Responsibility, Business Economics, Time Lag, Market Value, Market Capitalization, Tour and Travel, China

JEL Classification Code: M14, M16, M21, M41

\section{Introduction}

In the past four decades, corporate social responsibility (CSR) issues have grown substantially due to the increasing demand for transparency and growing expectations that corporations should manage and improve their social, environmental and economic performance. As a result, most of the Fortune Global 500 companies provide CSR reports, while a large number of companies are still engaged in defining and integrating CSR into several aspects of their business. However, each company has different policies and focuses on the implementation of CSR, depending on its size, industry, business culture, stakeholders' demands and how the companies have been engaged in CSR in the past.

${ }^{1}$ First Author and Corresponding Author. School of International Economics and Trade, Anhui University of Finance and Economics (AUFE), China [Postal Address: 962 Caoshan Road, Bengbu City, Anhui Province, China 233030] Email: jungwan.lee@aufe.edu.cn

(c) Copyright: The Author(s)

This is an Open Access article distributed under the terms of the Creative Commons Attribution Non-Commercial License (http://Creativecommons.org/licenses/by-nc/4.0/) which permits unrestricted noncommercial use, distribution, and reproduction in any medium, provided the original work is properly cited.
Therefore, in order to have a successful implementation, the companies must make sure that their CSR strategy aligns with the company's mission and objectives, where CSR will be a part of the company value chain in markets.

Other than the strategy alignment, costs are also another main concern in CSR implementation. These costs include the purchase of environmentally-friendly equipment and the adoption of management best practice. With the expectation from shareholders to gain the highest return with the least risk and loss, corporations unlikely want to generate negative cash flows from their investment. Therefore, their investment in CSR should yield some expected bottom-line benefits. In many cases, the limitation in the alignment of costs and benefits is the time frame, where the costs are immediate but the benefits are not often realized quickly.

This study aims to provide plausible answers to the question: "What is the time lag of CSR activity on the market value of tour operators and travel companies listed on Chinese stock markets?" The impact of time lags is that CSR activity may carry some immediate financial risks the impact of CSR activity would be reflected on the market value of the company with some adjustments of time lags. An issue standing in the way of measuring the impact of each of CSR activity is a time lag that occurs from the implementation 
of CSR activity to the actual economic returns of it. It is assumed that CSR activity normally takes a certain amount of time to have an economic effect on the market value of the firm on Chinese stock markets.

\section{Literature Review and Hypothesis Development}

\subsection{CSR Practices in the Travel and Tourism Industry of China}

Porter and Kramer (2006) indicated that CSR involves achieving commercial success in ways that honor ethical values and respect people, communities, and the natural environment. Yusoff et al. (2013) stated that CSR requires organizations to conduct business that does not harm the marketplace, workplace, the community in which they operate, and the natural environment. Some CSR programs are simply public relations campaigns or charitable donations, which these activities have nothing to do with either its business operation or social and community concerns (Jones et al., 2006). Jones et al. (2006) stated that companies are pressured by activists, customers, employees and governments to be socially responsible and understand the need of CSR activity reports. Holcomb et al. (2007) stated that initiatives for sustainable tourism and CSR in the travel and tourism sector have been striving for the past ten years by international and European organizations. Due to the increase attention, World Tourism Organization (UNWTO) has been adopting ethical guidelines by more and more local associations and organizations. Thus, it is obvious that CSR is becoming accepted more globally. Holcomb et al. (2007) also suggested that most tour operators and travel companies can improve their CSR reporting, and that tour operators and travel companies should manage their reputation of being 'sustainable' not only to their guests, but also to society.

As one of the biggest emerging economy in the world, China has attracted lots of international and domestic tourists. From 2008 to 2013, gross revenue generated from online tourism service increased from $\$ 7.65$ billion to $\$ 34.34$ billion, with year-on-year 25\% growth rate (Travel China Guide, 2016). In 2015, a total of 25.98 million foreigners visited China, and 20.28 million of them stayed at least one night (Travel China Guide, 2016). Many foreign tourists who visited China have witnessed significant changes in CSR activity in China. For example, Yunan is an ancient town where local indigenous people still live in and attracts millions of tourists across the world every year. "Faithful business practice" and "responsibility to tourists" are the two key principles suggested by the Yunan Bureau of Tourism Development (Su et al., 2013). One of the expressions of CSR in Lijiang is that Lijiang tourism development center tries best to ensure that tourists will not be cheated during their travel (Su et al., 2013). In China, however, because of historical administrative arrangements, natural and cultural tourism resources are mostly managed and regulated by governmental organizations rather than private corporations, the way of examining CSR activity is different (Wang and Ap, 2013). Although the executive power is in the local government, since the Chinese government practices a centralized governance system, CSR implementation process cannot always operates smoothly.

Belyaeva and Kazakov (2015) found that in China, the public sector is widely and actively involving CSR actions in order to better solve problems in terms of corporate governance, labor dispute, and environmental protections, especially within the travel and tourism industry. However, lacking cooperation between government departments is still common. As a result, promoting CSR activity remains difficult. Although China has its very own governmental system which might cause CSR implementation to be even more difficult, many private tour operators and travel companies start disclosing CSR reports to investors and public due to various reasons. The Chinese government has already developed a series of reporting standard for Chinese companies, suggesting how to file. The central government suggests a structural reform within China in which the form of economic growth will be shifted from speed-oriented to environmentally friendly-oriented. Besides, the Shanghai Stock Exchange and the Shenzhen Stock Exchange have issued guidelines and recommendations on reporting CSR activity (Lin, 2010). Therefore, listed corporations perceive reporting CSR activity is a desired activity (Marquis and Qian, 2013).

In an empirical study, 16 Chinese firms were examined with regard to their CSR activity. The findings show that Chinese firms interpret CSR as a series of ethical actions (Yin \& Zhang, 2012), such as employees' welfare, environment protection, ethical behavior, and productquality assurance. Yin and Zhang (2012) also pointed out that since there is a deeply-rooted corporate hierarchy in Chinese companies, unless top management actively promotes CSR implementation, the companies hardly execute their CSR comprehensively.

\subsection{CSR Activity and Corporate Financial Performance}

Rhou et al. (2016) suggest that stakeholders' CSR awareness affects the manner in which CSR initiatives can result in financial gains in firm performance. Many tour operators and travel companies are attempting to enhance their public images through CSR activity, such as recycling, supporting local communities, promoting diversity in the workplace, producing more products organically, and donating to charities (McGehee et al., 2009). Given this, a 
handful of research has investigated the effect of CSR activity on firm performance in tourism-related industries (e.g., Kang et al., 2010; Lee and Park, 2009). The fundamental question addressed in the literature is whether or not firms, actively involved in CSR initiatives, outperform other companies that do not demonstrate the same degree of CSR involvement (Lee and Park, 2009).

There are two types of studies on the relationship between CSR activity and corporate financial performance, i.e., shortterm and long-term. Both methods are used to investigate the impact on corporate financial performance when engaging in CSR activity, where accounting-based or market-based measures of profitability are being used for long-term measurement. Kang et al. (2010) found both positive and negative impact of CSR activity on a company's financial performance in the tourism industry. The findings of the study suggest that there is a significantly positive correlation between CSR and firm financial performance in the hotel industry (i.e. Tobin's Q), and positive correlation between CSR and return on equity in the casino industry. Meanwhile, Inoue and Lee (2011) find that CSR activity significantly decreases the airline industry's short-term profitability while increases the hotel and restaurant industry's long-term and short-term profitability. Nevertheless, the measuring methods of the effect of CSR whether it results in strong financial performance or not are still in the early stage of the development (Yusoff et al., 2013).

Tamajón and Font (2013) examine relationships between CSR and corporates financial performance in tourism small and medium enterprises across Europe and Latin America. The results indicate that companies that implement sustainability measures report better financial performance than the others. Companies outperforming financially also rank above average in terms of water saving energy recycling and local consumption promotion. On the other hand, Singal (2014) examines the relationships between CSR and financial performance in family business in the tourism industry. The results suggest that financial slack strongly influence CSR.

Recently, the tourism industry exhibited a growing interest in the economic relationship between CSR activity and their economic returns (Inoue and Lee, 2011). Inoue and Lee (2011) suggest that all CSR dimensions have positive financial effects, while each dimension had a differential effect on both short-term and future profitability and that such financial impacts varied across tourism-related industries. A widelyaccepted notion asserts that these improvements positively impact financial performance (Font et al., 2012; Campbell, 2007). However, despite popularity among tour operators and travel companies, few studies empirically test the economic impact of CSR activity on corporate financial performance (Kang et al., 2010). Further, the findings of existing studies have been inconclusive. A number of scholars found a positive relationship between CSR activity and corporate financial performance in the lodging and restaurant industries (Garcia and Armas, 2007; Lee and Park, 2009; Nicolau, 2008; Rodriguez and Cruz, 2007). Others found no significant association between CSR activity and corporate financial performance in the casino industry (Kang et al., 2010).

\subsection{CSR Activity and Time Lags of Economic Returns in Literature on Tourism}

Within the context of the tourism industry, studies on the relationship between CSR activity and corporate financial performance have inconclusive findings also. Some studies found that CSR activity positively impacts firm performance (e.g., Rodriguez and Cruz, 2007), while Singal (2014) finds that the relationship between CSR activity and financial performance can be bi-directional, supporting both instrumental theory (i.e., better CSR activity leads to better financial performance), and slack resources theory (i.e., better financial performance leads to better CSR activity). Other scholars report having fragmented results. For example, using an aggregate CSR measure, Park and Lee (2009) found tour operators and travel companies show an improved return on equity for their CSR efforts with the U-shaped relationship while finding no effect of CSR activity on the market-based measure (measured by total shareholder return). Inconsistent with the findings of Park and Lee (2009), Kang et al. (2010) examined disaggregated effects of positive and negative CSR activity on corporate financial performance and found no significant impact of both CSR activity on accounting profitability (i.e., return on equity and return on assets) while the effect of positive CSR activity on price-earnings ratio and Tobin's Q were positive in tour operators and travel companies. Their findings support the idea that concentrating on positive CSR activity is a more prudent CSR strategy and should be built into the long-term strategy of tour operators and travel companies.

More recently, Lee et al. (2013) parsed out different effects of operations-related and non-operations-related CSR activity while incorporating economic conditions into the relationship between CSR activity and corporate financial performance because the tourism industry is sensitive to economic fluctuations. The study found no significant effect of operations-related CSR activity on the firm financial performance of tour operators and travel companies (Tobin's Q) during favorable economic periods, while this activity added a firm's value during recessionary periods.

This study aims to investigate the impact of CSR activity on the market value of the firm. The negative relationship implicates the thinking of neoclassical economist, which socially responsible firms have a competitive disadvantage due to the incurred costs that could have been avoided by the firm. Thus, it results in the reduction of their profits. The argument for positive relationship is that the actual 
costs of CSR activity are covered by the benefits. Based on the statement above, the study has generated the following hypotheses for further verification.

Hypothesis 1: CSR activity is positively related to the market value of the firm with time lags.

Hypothesis 2: Both sales and Tobin Q are positively related to the market value of the firm.

Hypothesis 3: Risk ratio is negatively related to the market value of the firm.

\section{Data and Measurements}

\subsection{Data and Descriptive Statistics}

The sample data includes a total of 27 tour operators and travel companies listed on the Shanghai Stock Exchange or the Shenzhen Stock Exchange over a 12-year period, 20062017. The balanced panel data includes a total of 1,296 observations with 27 cross-sections of tour operators and travel companies listed on Chinese stock markets and with 48 time-specific periods from the 1st quarter, March 2006 to the 4th quarter, December 2017. Table 1 gives descriptive statistics for some important variables used in the study.

\subsection{Measurement of CSR Activity}

Due to the lack of consensus of measurement methodology and the use of subjective indicators, the link of how CSR activity and the market value of the firm is very complicated. Even though in some cases where researchers employ official corporate disclosures annual reports to shareholders and CSR reports, there is still no way to determine whether the data from corporations are under-reported or over-reported. Therefore, questions about measurement and subjective bias could still exist. In this study, a 5-point Likert scale is used to measure the CSR activity, with a maximum value of 5.0 if a firm involves CSR activity at the highest level in a given period and a minimum value of 0.5 otherwise.

\subsection{Correlation Analysis}

Table 2 presents the correlations between the explanatory variables and the market value of the firm. Although the

Table 1: Descriptive Statistics of the Sample for the Years 2006-2017

\begin{tabular}{|l|c|c|c|c|c|c|}
\hline & CSR & Market value & Sales & ROA & Tobin Q & Risk ratio \\
\hline Mean & 2.407 & $4.64 \mathrm{E}+09$ & $1.04 \mathrm{E}+09$ & 3.019 & 2.670 & 2.824 \\
\hline Median & 1.000 & $2.88 \mathrm{E}+09$ & $3.34 \mathrm{E}+08$ & 2.195 & 2.030 & 2.026 \\
\hline Maximum & 4.342 & $43.33 \mathrm{E}+09$ & $19.99 \mathrm{E}+09$ & 28.339 & 24.342 & 21.811 \\
\hline Minimum & 0.500 & $6.11 \mathrm{E}+08$ & 454838.9 & -18.565 & 0.125 & 0.081 \\
\hline Std. Dev. & 1.960 & $5.55 \mathrm{E}+09$ & $2.34 \mathrm{E}+09$ & 4.444 & 2.860 & 2.851 \\
\hline $\begin{array}{l}\text { Pooled panel } \\
\text { observations }\end{array}$ & 34263 & 34263 & 34263 & 34263 & 34263 & 34263 \\
\hline Cross sections & 27 & 27 & 27 & 27 & 27 & 27 \\
\hline
\end{tabular}

Table 2: Results of Correlation between Key Variables

\begin{tabular}{|c|c|c|c|c|c|}
\hline & CSR & Market value & Risk ratio & ROA & Sales \\
\hline Market value & $\begin{array}{l}0.657^{* * *} \\
{[31.069]}\end{array}$ & & & & \\
\hline Risk ratio & $\begin{array}{l}-0.899^{* * *} \\
{[-89.996]}\end{array}$ & $\begin{array}{l}-0.657^{* * *} \\
{[-31.069]}\end{array}$ & & & \\
\hline ROA & $\begin{array}{l}0.418^{* * *} \\
{[16.393]}\end{array}$ & $\begin{array}{l}0.292^{* * *} \\
{[10.898]}\end{array}$ & $\begin{array}{l}0.418^{* * *} \\
{[16.393]}\end{array}$ & & \\
\hline Sales & $\begin{array}{l}0.544^{* * *} \\
{[23.100]}\end{array}$ & $\begin{array}{l}0.481^{* * *} \\
{[19.573]}\end{array}$ & $\begin{array}{l}0.544^{* * *} \\
{[23.100]}\end{array}$ & $\begin{array}{c}0.946^{* * *} \\
{[104.123]}\end{array}$ & \\
\hline Tobin Q & $\begin{array}{l}0.669^{* * *} \\
{[32.104]}\end{array}$ & $\begin{array}{c}0.174^{* * *} \\
{[6.293]}\end{array}$ & $\begin{array}{l}-0.669^{* * *} \\
{[-32.104]}\end{array}$ & $\begin{array}{c}0.087^{* * *} \\
{[3.130]}\end{array}$ & $\begin{array}{l}0.152^{* * *} \\
{[5.481]}\end{array}$ \\
\hline
\end{tabular}

Correlation is significant at the 0.05 level $\left(* *, p<0.05\right.$ and $\left.{ }^{* * *}, p<0.01\right)$

Values in square brackets [ ] are t-statistics. 
variance inflation factor is not presented here due to the table space limit, this study found that the problem of multicollinearity does not appear to exist. Table 2 indicates that CSR has positive correlation with the market value $(\mathrm{p}<$ $0.01)$ and sales $(\mathrm{p}<0.01)$.

\section{Empirical Results}

\subsection{Unit Root Tests}

Many economic time series data are in general characterized by stochastic trends. When the autocovariances of the time series depend on time the time series data are said to be non- stationary, which indicates it has a unit root. The literature suggests that panel-based unit root tests have higher power than unit root tests based on individual time series (Im, Pesaran and Shin, 2003; Levin, Lin and Chu, 2002; Maddala and $\mathrm{Wu}, 1999$ ). For the purposes of testing, there are two natural assumptions about the autoregressive coefficient, First, one can assume that the persistence parameters are common across cross-sections so that for all cross-sections $i$. The Levin et al. (2002) unit root test employs this assumption and thus assumes that there is a common unit root process as the null hypothesis (alternative: there is no unit root) so that the autoregressive coefficient is identical across cross-sections.

Alternatively, one can allow to vary freely across crosssections. The Im et al. (2003) and Fisher type tests using $\mathrm{ADF}$ and PP tests are of this form. To test stationarity of the time series data this study also employs two panel-based unit root tests: Fisher-type augmented Dickey-Fuller test (Im et al., 2003) and Fisher-type Phillips-Perron test (Maddala and $\mathrm{Wu}, 1999)$. The probabilities for the two Fisher-type unit root tests were computed using an asymptotic chi-square distribution. All other tests assume asymptotic normality.
Table 3 displays the numeric values of the panel-based unit root tests for each time series. The panel unit root tests were conducted with the selection of individual effects that wish to include individual fixed effects, with the NeweyWest automatic bandwidth selection and Bartlett kernel estimation method, and with the selection of maximum lags of 2 .

At the level some of the null hypothesis (i.e. market value and CSR time series) cannot be rejected. This indicates the time series has time dependent stochastic trends in which the time series is non-stationary. When applied to the first difference of the time series all the null hypothesis can be rejected at the 0.01 significance level. This indicates all the time series are integrated of the first order and stationary at the first difference, also known as I (1).

\subsection{Results of Panel Regression Analysis}

The presence of cross-section and period specific effects may be handled using fixed or random effects methods. The fixed effects portions of specifications are handled using orthogonal projections. In the simple oneway fixed effect specifications and the balanced two-way fixed specification, these projections involve the familiar approach of removing cross-section or period specific means from the dependent variable and exogenous regressors, and then performing the specified regression using the demeaned data. Alternatively, the random effects specifications assume that the corresponding effects are realizations of independent random variables with mean zero and finite variance. Most importantly, the random effects specification assumes that the effect is uncorrelated with the idiosyncratic residual (Baltagi, 2005).

There are several types of panel data analytic models, including fixed effects and random effects models. The

Table 3: Results of Panel Unit Root Tests

\begin{tabular}{|l|c|c|c|c|c|}
\hline \multicolumn{1}{|c|}{ Time series } & Market value & CSR & Sales & Tobin Q & Risk ratio \\
\hline Test methods & $\begin{array}{c}\text { Level } \\
\text { 1st difference }\end{array}$ & $\begin{array}{c}\text { Level } \\
\text { 1st difference }\end{array}$ & $\begin{array}{c}\text { Level } \\
\text { 1st difference }\end{array}$ & $\begin{array}{c}\text { Level } \\
\text { 1st difference }\end{array}$ & $\begin{array}{c}\text { Level } \\
\text { 1st difference }\end{array}$ \\
\hline Levin et al. & -0.307 & $-7.319^{* * *}$ & $-12.935^{* * *}$ & $-16.229^{* * *}$ & $-14.131^{* * *}$ \\
& $-31.301^{* * *}$ & $-35.279^{* * *}$ & $-37.804^{* * *}$ & $-22.658^{* * *}$ & $-69.391^{* * *}$ \\
\hline Im et al. & 1.665 & $-3.186^{* * *}$ & $-23.472^{* * *}$ & $-15.361^{* * *}$ & $-8.837^{* * *}$ \\
& $-33.988^{* * *}$ & $-45.605^{* * *}$ & $-41.739^{* * *}$ & $-24.874^{* * *}$ & $-65.074^{* * *}$ \\
\hline Fisher-ADF & 23.237 & 70.600 & $565.638^{* * *}$ & $333.685^{* * *}$ & $175.012^{* * *}$ \\
& $858.432^{* * *}$ & $1107.360^{* * *}$ & $1039.350^{* * *}$ & $603.253^{* * *}$ & $1211.900^{* * *}$ \\
\hline Fisher-PP & $95.950^{* * *}$ & $187.333^{* * *}$ & $769.455^{* * *}$ & $305.924^{* * *}$ & $187.333^{* * *}$ \\
& $1242.690^{* * *}$ & $1076.840^{* * *}$ & $602.190^{* * *}$ & $1231.600^{* * *}$ & $1076.840^{* * *}$ \\
\hline
\end{tabular}

Probability values for rejection of the null hypothesis of a unit root are employed at the 0.05 level $\left({ }^{* * *}, p<0.01\right)$. 
Hausman test is used to determine which of the two methods should be employed. It tests whether the unique errors are correlated with the regressors; the null hypothesis is that they are not. Probabilities are computed using the chisquared distribution. If the procedure of the statistical test shows the null hypothesis is not rejected, the random effects method is chosen. The result of the Hausman test indicates that the fixed effects model is more robust for the case of the regression specifications with the current balanced panel data (cross section random chi-square statistic $=35.904$, p-value $<0.01)$.

Table 4 reports the results of the panel regression analysis. In Table 4, the numeric values in the cells are coefficients of regressors, which indicate short-run elasticity of the endogenous variable for the dependent variable.

In testing hypothesis 1 that CSR activity is positively related to the market value of the firm with time lags, Table 4 indicates that the hypothesis is supported at the 0.01 level. The results suggest that a one percent rise in CSR activity decreases the market value by 0.005 percent for the concurrent time period, but afterwards increases by 0.005 percent with a one-period time $\operatorname{lag}(-1)$ and continue to increase by 0.011 percent even with a two-period time lag(-2).

In testing hypothesis 2 that both sales and Tobin $\mathrm{Q}$ are related to the market value of the firm, Table 4 indicates that the hypothesis is supported at the 0.01 level. The results

Table 4: Results of Panel Regression Analysis

\begin{tabular}{|c|c|c|}
\hline Cross section & Fixed Effects & Random Effects \\
\hline Estimation method & Pooled Least Squares & $\begin{array}{c}\text { Pooled EGLS } \\
\text { (cross section random effects) }\end{array}$ \\
\hline CSR & $\begin{array}{l}-0.005^{* *} \\
{[-2.639]}\end{array}$ & $\begin{array}{l}-0.005^{* *} \\
{[-2.668]}\end{array}$ \\
\hline $\operatorname{CSR}(-1)$ & $\begin{array}{l}0.005^{* *} \\
{[2.410]}\end{array}$ & $\begin{array}{l}0.005^{\star *} \\
{[2.394]}\end{array}$ \\
\hline $\operatorname{CSR}(-2)$ & $\begin{array}{l}0.011^{* * *} \\
{[6.586]}\end{array}$ & $\begin{array}{l}0.011^{* * *} \\
{[6.540]}\end{array}$ \\
\hline Sales & $\begin{array}{l}0.172^{* * *} \\
{[104.243]}\end{array}$ & $\begin{array}{c}0.172^{* * *} \\
{[104.365]}\end{array}$ \\
\hline Tobin Q & $\begin{array}{l}0.111^{* * *} \\
{[58.971]}\end{array}$ & $\begin{array}{l}0.111^{* * *} \\
{[58.954]}\end{array}$ \\
\hline Risk ratio & $\begin{array}{l}-0.056 * * * \\
{[-51.041]}\end{array}$ & $\begin{array}{l}-0.056^{* * *} \\
{[-50.984]}\end{array}$ \\
\hline Constant & 18.365 & 18.362 \\
\hline R-squared & 0.887 & 0.351 \\
\hline Adjusted R-squared & 0.887 & 0.351 \\
\hline F-statistic & $8109.610^{* * *}$ & $2959.413^{* * *}$ \\
\hline Durbin-Watson statistic & 0.876 & 0.876 \\
\hline Included observations & 1215 after adjustments & 1215 after adjustments \\
\hline Included cross sections & 27 & 27 \\
\hline Total pool observations & 32805 & 32805 \\
\hline \multirow[t]{2}{*}{$\begin{array}{l}\text { Redundant cross section fixed effects } \\
\text { test }\end{array}$} & $\begin{array}{l}\text { Cross section }(\text { d.f. }=26) \\
\text { F-statistic }=4327.442^{* * *}\end{array}$ & $\begin{array}{l}\text { Cross section random effects } \\
\text { Rho }=0.765\end{array}$ \\
\hline & $\begin{array}{c}\text { Cross section (d.f. }=26) \\
\text { Chi-square statistic }=48850.787^{* * *}\end{array}$ & $\begin{array}{c}\text { Idiosyncratic random effects } \\
\text { Rho }=0.234\end{array}$ \\
\hline
\end{tabular}

Regression model: Market value $=$ CSR + CSR $(-1)+C S R(-2)+$ Sales + Tobin $Q+$ Risk ratio

The numeric values in [ ] are t-statistics.

Probabilities for rejection of the null hypothesis are employed at the 0.05 significance level $\left({ }^{* *}, p<0.05\right.$ and $\left.{ }^{* *}, p<0.01\right)$. 
suggest that a one percent hike in sales increases the market value by 0.172 percent and a one percent hike in Tobin $\mathrm{Q}$ increases the market value by 0.111 percent.

In testing hypothesis 3 that risk ratio is related to the market value of the firm, Table 4 indicates that the hypothesis is supported at the 0.01 level. The result suggests that a one percent hike in risk ratio decreases the market value by 0.056 percent.

\section{Discussion and Implication}

The results of the study indicate that, though CSR activity has a negative impact on the market value of the firm for the concurrent time period, from one-period time lag and afterwards CSR activity has a strong positive impact on the market value and sustains its positive impact on the market value even for a two-period time lag on Chinese stock markets. The findings suggest that the economic effect of CSR activity on the firm market value tends to take some degree of lagged effects to be fully showcased in the market capitalization of tour operators and travel companies listed on Chinese stock markets.

The results of the study suggest that, though CSR practices of Chinese tour operators and travel companies are neutral over a prolonged period, those companies active in CSR activity tend to have yielded strong positive economic returns in the market. The findings of time lags in this study are quite some contribution to the literature. For example, the results show that CSR activity has a negative impact on the market value of the firm for the concurrent time period with maximum three months, but afterwards CSR activity has yielded strong positive economic returns in the market even up to following nine months. What stands out from the results is that, while some consensus exists on the overall pattern of lags in the economic returns of CSR activity, the findings of the exact length of time lags and validity across Chinese tour operators and travel companies are virtually identical.

According to the stakeholder theory, CSR activity is considered a prominent form of shareholder management (Theodoulidis et al., 2017). In particular, the increased social pressure and the expected benefits of CSR activity have become apparent in the current competitive travel and tourism industry (Sparks et al., 2003). In the travel and tourism industry, many firms largely operate as multinational companies and so CSR activity may be a major strategic factor for successful operation of those firms in local markets. In fact, many CSR policies and practices are based on localized issues and cultural tradition at the country level (Kang et al., 2016). Therefore, CSR activity is a fruitful avenue for tour operators and travel companies to maximize corporate market value in the local market. Since the travel and tourism industry is known for its competitiveness and tight profit margins (Raab et al., 2007), business managers of the travel and tourism industry are especially inclined to reduce the economic uncertainty of their business in the short-term while at the same time they emphasize better strategic choices that are able to improve their business financial performance and management efficiency at the long-term.

Lee et al. (2013) claimed that operations related CSR activity have a positive effect on firms' financial performance of tour operators and travel companies. If tour operators and travel companies have very limited financial resources, business managers of tour operators and travel companies tend to become even more risk-averse when making investment decisions, especially regarding CSR commitments. Consequently, business managers are likely to seek alternative investment opportunities that may bring more tangible financial and/or operational returns at the shortterm, instead of making CSR commitments to discretionary long-term strategies. For example, business managers may pursue investments in more operation related areas instead of CSR activity so that the return on their investments can be more easily observed in immediate financial statements.

In this setting, the identification of time lags and sign in the relationship between CSR activity and economic returns on Chinese stock markets from this study reinforces and suggests that, though CSR activity may carry some financial risk for an immediate short-term, tour operators and travel companies must put a lot of time and effort into making CSR actions effective since the current initiatives guarantee better economic outcome in the market in the near future. The presence of time lags means that decision-makers must recognize that decisions on CSR activity may carry some delayed economic returns in the market in China. This may not be likable, as decision makers require good balance between commitments to CSR activity in order to meet the social expectations of stakeholders and commitments to better return on investments (bottom-line) in order to meet the immediate economic expectations of shareholders. At any point, the real output of CSR activity takes time to be fully showcased on the market value of the firm. For example, those companies not and/or less involved in CSR activity could experience much cost cuts at the short-term but at the same time they would face the unappealing choice of raising their economic returns at the long-term. While decisions to CSR activity can be changed quickly and shortly, the chain of events consequent to CSR actions cannot be reversed.

The purpose of the research on time lags is to determine how they constrain decisions on CSR activity of Chinese tour operators and travel companies. Can CSR activity positively change the market value of the firm?, or is it so limited by time lags that CSR activity designed to positively change the market value of the firm may actually exacerbate the business cycle of the firm?, which was generally common to nearly all 
of the companies surveyed in the study. The significance of time lags for CSR activity must be interpreted in considering possible differences in results across international stock markets. In sum, the findings of the study have shown that CSR activity of Chinese tour operators and travel companies has yielded significant positive economic effects on the market value of the firm though there have existed some time lags in the process. The findings of the study suggest that the triple bottom-line of measuring economic, environmental, and social profit and losses must be embraced for tour operators and travel companies across the world.

\section{Conclusion and Limitation}

The findings from this study indicate that the relationship between CSR activity and the market value of the firm is significant with time lags, where the actual costs of CSR activity could be covered by its prolonged economic benefits. In addition, those firms that are actively involved in CSR activity may increase their reputation, while those firms that attempt to reduce CSR activity may result in an unappealing effect of their reputation. Therefore, CSR activity should be integral to the long-term success of the company. Business and society are dependent upon each other and both must align, or neither will thrive in the future.

For further research of this issue, more extensive evidence is necessary. For further verification of the relationship between CSR activity and economic returns of the firm over a period of time, a better systematic investigation of the relationship with time series is needed. In addition, as CSR data is obtained through several sources with different evaluation methods, more reliable and comparable CSR data should be developed and employed in the future.

\section{References}

Baltagi, B. H. (2005). Econometric Analysis of Panel Data, (3rd ed.). West Sussex, England: John Wiley \& Sons.

Belyaeva, Z., \& Kazakov, A. (2015). Integrated approach to social responsibility: A model of stakeholders interaction in Russia and China. Systems Research and Behavioral Science, 32(2), 240-246.

Campbell, J. L. (2007). Why would corporations behave in socially responsible ways? An institutional theory of corporate social responsibility. Academy of Management Review, 32(3), 946-967.

Font, X., Walmsley, A., Cogotti, S., McCombes, L., \& Häusler, N. (2012). Corporate social responsibility: The disclosureperformance gap. Tourism Management, 33(6), 1544-1553, https://doi.org/10.1016/j.tourman.2012.02.012.

Garcia, F., \& Armas, Y. (2007). Relationship between socialenvironmental responsibility and performance in hotel firms.
International Journal of Hospitality Management, 26(4), 824839.

Holcomb, J. L., Upchurch, R. S., \& Okumus, F. (2007). Corporate social responsibility: What are top hotel companies reporting? International Journal of Contemporary Hospitality Management, 19(6), 461-475.

Im, K. S., Pesaran, M. H., \& Shin, Y. (2003). Testing for unit roots in heterogeneous panels. Journal of Econometrics, 115(1), 5374.

Inoue, Y., \& Lee, S. (2011). Effects of different dimensions of corporate social responsibility on corporate financial performance in tourism-related industries. Tourism Management, 32(4), 790-804, https://doi.org/10.1016/j. tourman.2010.06.019.

Jones, P., Comfort, D., \& Hillier, D. (2006). Reporting and reflecting on corporate social responsibility in the hospitality industry. International Journal of Contemporary Hospitality Management, 18(4), 329-340.

Kang, K. H., Lee, S., \& Huh, C. (2010). Impacts of positive and negative corporate social responsibility activities on company performance in the hospitality industry. International Journal of Hospitality Management, 29(1), 72-82. https://doi. org/10.1016/j.ijhm.2009.05.006

Kang, K. H., Lee, S., \& Yoo, C. (2016). The effect of national culture on corporate social responsibility in the hospitality industry. International Journal of Contemporary Hospitality Management, 28(8), 1728-1758.

Lee, S., \& Park, S. Y. (2009). Do socially responsible activities help hotels and casinos achieve their financial goals? International Journal of Hospitality Management, 28(1), 105-112.

Lee, S., Seo, K., \& Sharma, A. (2013). Corporate social responsibility and firm performance in the airline industry: The moderating role of oil prices. Tourism Management, 38, 20-30, https://doi.org/10.1016/j.tourman.2013.02.002.

Lee, S., Singal, M., \& Kang, K. H. (2013). The corporate social responsibility-financial performance link in the US restaurant industry: Do economic conditions matter? International Journal of Hospitality Management, 32, 2-10.

Levin, A., Lin, C. F., \& Chu, C. J. (2002). Unit root tests in panel data: asymptotic and finite-sample properties. Journal of Econometrics, 108, 1-24.

Lin, L. W. (2010). Corporate social responsibility in China: Window dressing or structural change? Berkeley Journal of International Law, 28(1), 64-100.

Maddala, G. S., \& Wu, S. (1999). A comparative study of unit root tests with panel data and a new simple test. Oxford Bulletin of Economics and Statistics, 61(S1), 631-652.

Marquis, C., \& Qian, C. (2013). Corporate social responsibility reporting in China: Symbol or substance? Organization Science, 25(1), 127-148.

McGehee, N. G., Wattanakamolchai, S., Perdue, R. R., \& Calvert, E. O. (2009). Corporate social responsibility within the U.S. 
lodging industry: An exploratory study. Journal of Hospitality \& Tourism Research, 33(3), 417-437.

Nicolau, J. L. (2008). Corporate social responsibility: worthcreating activities. Annals of Tourism Research, 35(4), 990-1006.

Park, S., \& Lee, S. (2009). Financial rewards for social responsibility: a mixed picture for restaurant companies. Cornell Hospitality Quarterly, 50(2), 168-179.

Porter, M., \& Kramer, M. (2006). Strategy \& society: The link between competitive advantage and corporate social responsibility. Harvard Business Review, 84(12), 78-92.

Raab, C., Shoemaker, S., \& Mayer, K. J. (2007). Activity-based costing: A more accurate way to estimate the costs for a restaurant menu. International Journal of Hospitality \& Tourism Administration, 8(3), 1-15.

Rhou, Y., Singal, M., \& Koh, Y. (2016). CSR and financial performance: The role of CSR awareness in the restaurant industry. International Journal of Hospitality Management, 57, 30-39, https://doi.org/10.1016/j.ijhm.2016.05.007.

Rodriguez, F. R. G., \& Cruz, Y. D. M. A. (2007). Relation between social-environmental responsibility and performance in hotel firms. International Journal of Hospitality Management, 26(4), 824-839.

Singal, M. (2014). Corporate social responsibility in the hospitality and tourism industry: Do family control and financial condition matter? International Journal of Hospitality Management, 36, 81-89.
Sparks, B., Bowen, J., \& Klag, S. (2003). Restaurants and the tourist market. International Journal of Contemporary Hospitality Management, 15(1), 6-13.

Su, X., Wang, H., \& Wen, T. (2013). Profit, responsibility, and the moral economy of tourism. Annals of Tourism Research, 43, 231-250.

Tamajón, L. G., \& Font, X. (2013). Corporate social responsibility in tourism small and medium enterprises evidence from Europe and Latin America. Tourism Management Perspectives, 7, 38-46.

Theodoulidis, B., Diaz, D., Crotto, F., \& Rancati, E. (2017). Exploring corporate social responsibility and financial performance through stakeholder theory in the tourism industries. Tourism Management, 62, 173-188.

Travel China Guide. (2016). China Inbound Tourism in 2015. Retrieved July 30, 2018 from https://www.travelchinaguide. com/tourism/2015statistics/inbound.htm

Wang, D., \& Ap., J. (2013). Factors affecting tourism policy implementation: A conceptual framework and a case study in China. Tourism Management, 36, 221-233.

Yin, J., \& Zhang, Y. (2012). Institutional dynamics and corporate social responsibility (CSR) in an emerging country context: Evidence from China. Journal of Business Ethics, 111(2), 301-316.

Yusoff, H., Mohamad, S. S., \& Darus, F. (2013). The influence of CSR disclosure structure on corporate financial performance: Evidence from stakeholders' perspectives. Procedia Economics and Finance, 7, 213-220. 